Published every January - June and July - December

JURNAL ASET (AKUNTANSI RISET)

ISSN : 2541-0342 (Online). ISSN : 2086-2563 (Print). http://ejournal.upi.edu/index.php/aset

\title{
Pengaruh Pengawasan Persediaan Barang Terhadap Pengelolaan Perputaran Persediaan Barang di Toserba Yogya
}

\author{
Henda Hendawati ${ }^{1}$, Vicky Livi Anggiani². \\ Jurusan Akuntansi, Fakultas Ekonomi, Universitas Sangga Buana YPKP, Bandung, Indonesia.
}

\begin{abstract}
The purpose of this study is to understanding the influence of inventory control on inventory turnover management that applied by Toserba Yogya. Descriptive-associative research method is used with survey approach. Survey research is used to get observation data, questioner, and structured interviews forrelated organizational unit of inventory management. The objects of this study are inventory control as the independent variable and inventory turnover management as the dependent variable. The results of data processing shows the inventory control at Toserba Yogya has done well with the correlation coefficient of inventory control to inventory turnover management equal to 0.986 (98.6\%).
\end{abstract}

Keywords. inventory; management; inventory control

Abstrak. Tujuan penelitian ini yaituuntuk mengetahui sejauh mana pengaruh pengawasan persediaan barang yang diterapkan oleh Toserba Yogya terhadap pengelolaan perputaran persediaan barang.Metode penelitian yang digunakan adalah penelitian deskriptif asosiatif dengan pendekatan survey.Metode penelitian survey digunakan untuk mendapatkan data observasi, kuesioner, dan juga wawancara terstruktur pada unit organisasi yang terkait dalam pengaruh manajemen persediaan barang dagang terhadap perputaran barang dagang. Objek penelitian pada penelitian ini terdiri dari dua variable, yaitu pengawasan persediaan barang dagang sebagai variabel bebas dan pengelolaan perputaran persediaan barang sebagai variabel tidak bebas. Hasil pengolahan data menunjukan pengawasan persediaan barang dagang di Toserba Yogya sudah dilakukan secara baik sehingga sangat berperan pada pengelolaan perputaran persediaan barang. Nilai koefisien korelasi Pengawasan Persediaan Barang Dagang dengan Pengelolaan Perputaran Persediaan adalah sebesar 0.986 atau 98,6\%.

Kata Kunci. persediaan; pengelolaan; pengawasan persediaan barang.

Corresponding author. J1. PHH Mustofa (Suci) No 68. Kota Bandung. Provinsi Jawa Barat. Email: hendahendawati@gmail.com

How to cite this article. Hendayati \& Anggiani. (2015). Pengaruh Pengawasan Persediaan Barang Terhadap Pengelolaan Perputaran Persediaan Barang di Toserba Yogya. Jurnal Aset (Akuntansi Riset). Program Studi Akuntansi Fakultas Pendidikan Indonesia Universitas Pendidikan Indonesia, 7 (1), 1-12. Retrieved from http://ejournal.upi.edu/index.php/aset

History of article. Received: Januari 2015, Revision: Maret 2015, Published: Juni 2015 


\section{PENDAHULUAN}

Persediaan (inventory) merupakan barang dagangan yang utama dalam perusahaan dagang. Persediaan termasuk dalam golongan aset lancar perusahaan yang berperan penting dalam menghasilkan laba perusahaan. Secara umum istilah persediaan dipakai untuk menunjukkan barang-barang yang dimiliki untuk dijual kembali atau digunakan untuk memproduksi barang-barang yang akan dijual. Dalam perusahaan dagang, persediaan merupakan barang-barang yang diperoleh atau dibeli dengan tujuan untuk dijual kembali tanpa merubah barang itu sendiri.

Perusahaan harus dapat mempertahankan suatu jumlah persediaan yang optimum yang dapat menjamin kebutuhan bagi kelancaran kegiatan dalam jumlah dan mutu yang tepat serta dengan biaya yang serendahrendahnya.Semakin tinggi perputaran persediaan menunjukkan bahwa perusahaan berusaha bekerja secara efisien dan likuiditas persediaan semakin membaik. Demikian pula apabila perputaran persediaan rendah berarti perusahaan bekerja secara tidak efisien atau tidak produktif dan banyak barang persediaan yang menumpuk.

Tingginya kebutuhan pasar dan besarnya permintaan konsumen di Indonesia, menjadikan bisnis retail mengalami perkembangan yang cukup pesat. Toserba Yogya adalah salahsatu perusahaan retail modern asli Indonesia dengan format Supermarket dan Department Store. Toserba Yogya menjual berbagaiproduk mulai dari makanan, minuman, pakaian, kosmetik, barang elektronik, perlengkapan rumah tangga dan barang kebutuhan lainnya. Setiap minggunya Toserba Yogya melayani lebih dari 100 ribu pelanggan di lebih dari 100 titik yang tersebar di beberapa kota di sebagian wilayah Jawa Barat dan Jawa Tengah.Untuk menjaga ketersediaan produk, proses pengiriman dan penerimaan barang dari pengadaannya, penyimpanannya, sampai pengeluarannya harus ada pada waktu yang diperlukan, dengan kuantitas dan kualitas yang memadai, juga pada tempat yang tepat dan harga yang wajar.
Pengabaian salah satu tanggung jawab yang menyangkut persediaan akan membawa dampak negatif bagi kelancaran perputaran persediaan yang merupakan operasi perusahaan. Oleh sebab itu penting sekali terlaksananya pengawasan atas persediaan barang dikarenakan tingkat perputarannya yang sangat cepat.

Persediaan barang di setiap toko selalu mengalami perubahan. Perubahan tersebut ditunjukan dengan hasil laporan setiap toko pada akhir triwulan. Terdapat jumlah persediaan yang besar karena Toserba Yogya merupakan sebuah perusahaan retail, dan yang terpenting adalah persediaan barang dagang sangat berpengaruh terhadapperputaran barang dagang. Salah satu fenomena yang menandai hal tersebut, yaitu dengan semakin berkembangnya suatu perusahaan yang menuntut pengawasan yang ketat untuk mengontrol perputaran persediaan barang dagangan, yang dengan sendirinya pemeriksaan manajemen secara komprehensif, menjadi sangat penting pula.

Pengawasan atas persediaan yang baik dapat menciptakan pengelolaan perputaran persediaan barang dagang yang baik dan juga efektif dalam menentukan jumlah persediaan yang optimal yang dimiliki perusahaan, mencegah berbagai tindakan pelanggaran dan penyelewengan yang dapat merugikan perusahaan, pelanggaran terhadap kebijakan yang ditetapkan atas persediaan, serta memberikan pengamanan fisik terhadap persediaan dari pencurian dan kerusakan.

Banyaknya penumpukan barang di gudang membuat tingginya tingkat pengembalian barang kembali pada pihak supplier atau pemusnahan barang dagangan, hal seperti ini membuat kendala untuk dapat melakukan perputaran persediaan dengan baik seperti yang diharapkan, terdapat pula permasalahan yang dihadapi department fresh dalam hal penanganan persediaan produk makanan segar di Toserba Yogya yaitu broken stock yang sering kali berlebihan atau terlalu besar adalah handling product yang kurang baik dari barang datang sampai tahap pemajangan (display) 
sehingga buah-buahan juga sayur menjadi cepat rusak. Broken stock bisa terjadi akibat persediaan yang berlebih karena permintaan yangberfluktuasi sehingga persediaan menjadi berlebih.

Penelitian ini bertujuan untuk mengetahui sejauh mana pengaruh pengawasan persediaan barang yang diterapkan oleh Toserba Yogya terhadap pengelolaan perputaran persediaan barang. Penelitian ini diharapkan dapat memberikan masukan yang bermanfaat untuk perusahaan dan juga menambah pengetahuan mengenai pengawasan persediaan barang untuk mengatasi permasalahan-permasalahan yang timbul dari ketidakefisienan perputaran persediaan barang.

\section{KAJIAN LITERATUR}

\section{Pengertian Pengawasan Persediaan}

Pengawasan adalah sebagai suatu usaha sistematis oleh manajemen untuk membandingkan kinerja standar, rencana atau tujuan yang telah ditentukan terlebih dahulu untuk menentukan apakah kinerja sejalan dengan standar tersebut dan untuk mengambil tindakan penyembuhan yang diperlukan untuk melihat bahwa sumber daya manusia digunakan dengan seefektif dan seefisien mungkin didalam mencapai tujuan.

Menurut Supriyono (2000), pengertian dari pengawasan persediaan bahan adalah suatu fungsi terkoordinasi dalam organisasi yang terus menerus disempurnakan untuk meletakkan pertanggungjawaban atas pengelolaan bahan baku dan persediaan pada umumnya, sertamenyelenggarakan suatu pengendalian internal yang menjamin adanya dokumen dasar pembukuan yang mendukung sahnya suatu transaksi yang berhubungan dengan bahan baku.

Pengawasan persediaan bahan tidak hanya meliputi pengawasan terhadap fisik bahan tersebut saja, tetapi juga meliputi pengawasan akuntansi yakni menyangkut semua prosedur, dokumen, dan catatan pengawasan bahan baku serta dapat dipercayanya catatan keuangan yang mendukung kebenaran nilai transaksi tersebut.Pengawasan bertujuan agar hasil pelaksanaan pekerjaan diperoleh secara berdaya guna (efisien) dan berhasil guna (efektif) sesuai dengan rencana yang telah ditentukan sebelumnya (Simbolon,2004). Agar tujuan tersebut tercapai, maka akan lebih baik jika tindakan kontrol dilakukan sebelum terjadi penyimpangan-penyimpangan sehingga bersifat mencegah (preventif control) dibandingkan dengan tindakan kontrol sesudah terjadi penyimpangan (repressive control).Denganmelakukan pengawasan persediaan, objek pengawasan dapat diketahui kinerjanya, sehingga jika terjadikesalahan dapat diperbaiki dengan segera.

\section{Pengertian Persediaan Barang}

Setiap perusahaan retail perlu memiliki persediaan untuk menjamin kelangsungannya. Mereka harus mampu mempertahankan jumlah persediaan optimum untuk menjamin kebutuhan bagi kemajuan kegiatan perusahaan, baik secara kuantitas maupun kualitas.

Persediaan pada umumnya merupakan salah satu jenis aktiva lancar yang jumlahnya cukup besar dalam suatu perusahaan. Hal ini mudah dipahami karena persediaan merupakan faktor penting dalam menentukan kelancaran operasi perusahaan. Persediaan merupakan bentuk investasi, dari mana keuntungan (laba) itu bisa diharapkan melalui penjualan di kemudian hari. Oleh sebab itu pada kebanyakan perusahaan sejumlah minimal persediaan harus dipertahankan untuk menjamin kontinuitas dan stabilitas penjualannya.

Persediaan menurut Standar Akuntansi Keuangan yang dikeluarkan olehIkatan Akuntan Indonesia (2008), didefinisikan sebagai aset yang tersedia untuk dijual dalam kegiatan usaha biasa,dalam proses produksi atau penjualan, dan juga dalam bentuk badan atau perlengkapan untuk digunakan dalam proses produksi atau pemberian jasa.

Jenis-jenis persediaan berbeda sesuai dengan bidang atau kegiatan normal usaha perusahaaan tersebut. Berdasarkan bidang usaha perusahaaan dapat terbentuk perusahaan industri (manufacture), perusahaan dagang ataupun perusahaan jasa. Untuk perusahaan industri maka jenis persediaan yang dimiliki 
adalah persediaan bahan baku (raw material), barang dalam proses (work inprocess), persediaan barang jadi (finished goods), serta bahan pembantu yangakan digunakan dalam proses produksi. Untuk perusahaan dagang maka persediaanya hanya satu yaitu barang dagangan.

Persediaan barang itu sendiri mengalami siklus yang disebut siklus persediaan, yaitu menyangkut arus fisik barang-barang (physical flows ofgoods) dan arus biaya-biaya yang berhubungan (related cost). Oleh karena itu, perluadanya manajemen persediaan barang yang baik dalam suatu perusahaan. Menurut Arens, dkk (2003) fungsi yang terdapat dalam siklus persediaan yaitu meliputi pengolahanorder pembelian, penerimaan dan penyimpanan bahan baku, juga pengolahan, penyimpanan dan pengiriman barang jadi.

\section{Pembahasan Pengelolaan Persediaan Barang Dagangan}

Unsur persediaan menurut La Midjan dan Susanto (2001) terdiri dari prosedur penerimaan barang, penyimpanan Barang, dan prosedur pengeluaran barang.Suatu pengelolaan persediaan barang dagangan dikatakan efektif jika terdapat penetapan tanggung jawab dan kewenangan yang jelas terhadap persediaan, sasaran dan kebijakan yang dirumuskan dengan baik, fasilitas pergudangan dan penanganan yang memuaskan, klasifikasi dan identifikasi persediaan yang layak, standarisasi dan simplikasi persediaan, catatan dan laporan yang cukup dan tenaga kerja yang memuaskan (Willson and Campbell, 2001).

\section{Pengertian Perputaran Persediaan}

Perputaran persediaan merupakan berapa kali persediaan akan berputar dan kembali lagi. Dari rasio perputaran persediaan barang dapat diketahui efisiensi biaya yang berguna untuk memperoleh laba yang tinggi.Semakin cepat perputaran persediaan dalam siklus produksi normal, semakin baik karena dianggap kegiatan penjualan berjalan dengan cepat (Harahap, 2006). Perputaran persediaan memperlihatkan bagaimana persediaan dikelola dan dijual dalam suatu periode tertentu, sehingga persediaan akan selalu berputar dan nilainya akan berubah-ubah.

Pada neraca, persediaan dicatat atas dasar biaya. Artinya tidak ada unsur margin dalam nilai persediaan yang tercantum di neraca. Sementara penjualan yang terjadi dicatat atas dasar biaya ditambah margin. Apabila nilai penjualan dipakai sebagai dasar menghitung aktivitas menggunakan basis yang tidak mengandung unsur laba yaitu harga pokok penjualan, peningkatan atau penurunan jumlah perputaran persediaan ditentukan dari pembagian harga pokok penjualan dengan persediaan.

\section{Hubungan \\ Pengawasan \\ PersediaanBarangdenganPengelolaan \\ Perputaran Persediaan}

Pengawasan persediaan (Inventory Control) adalah kegiatan yang berhubungan dengan perencanaan, pelaksanaan penentuan kebutuhan material sehingga kebutuhan operasi dapat dipenuhi pada waktunya dan perputaran persediaan dapat ditekan secara optimal (Indrajit dan Pranoto, 2003). Maksud dari pengawasan persediaan itu sendiri adalah untuk mengawasi jumlah persediaan yang disimpan yaitu seberapa banyak persediaan yang disimpan, berapa banyak yang harus dipesan, dan kapan persediaan harus diisi kembali.

Inventory atau persediaan barang sebagai elemen utama dari modal kerjamerupakan aktiva yang selalu dalam keadaaan berputar, dimana secata terus menerus mengalami perubahan. Masalah investasi dalam inventory merupakan masalah pembelanjaan aktif ; seperti halnya investasi dalam aktiva - aktiva lainnya.

Investasi yang dimiliki perusahaan salah satunya akan tertanam pada persediaan. Persediaan bahan mentah diperlukan untuk dapat melakukan proses produksi, persediaan barang jadi adalah untuk melakukan penjualan secara lancar, persediaan bahan mentah dan barang dalam proses diperlukan untuk menjaminkelancaran proses produksi, sedangkan barang jadi harus selalu tersedia agar memungkinkan perusahaan memenuhi permintaan yang timbul. 
Pengawasan persediaan melakukan perencanaan, arahan agar dapat melakukan pengelolaan perputaran barang dagang dengan baik. Tingkat perputaran persediaan memberi informasi tentang kecepatan rata-rata aliran keluar-masuknya barang (dagangan) di dalam siklus operasi perusahaan.Semakin pendek umur rata - rata suatu inventory, semakin likuid atau aktif inventory tersebut (Syamsudin, 2002)

\section{METODOLOGI PENELITIAN Metode Penelitian dan Data yang digunakan}

Metode penelitian yang digunakan pada penelitian ini adalah penelitian deskriptif asosiatif dengan pendekatan survey. Metode penelitian survey digunakan untuk mendapatkan data dari tempat tertentu yang alamiah (bukan buatan), tetapi peneliti melakukan perlakuan dalam pengumpulan data, misalnya dengan menggunakan data primer yang diambil dari hasil observasi, dokumentasi, wawancara, dan kuesioner.

Teknik pengambilan sampel yang digunakan adalah purposive random sampling yang merupakan suatu tipe sampling probabilitas, di mana peneliti dalam memilih sampel dengan memberikan kesempatan yang sama kepada semua anggota populasi untuk ditetapkan sebagai anggota sampel. Dengan teknik semacam itu maka terpilihnya individu menjadi anggota sampel denga benar-benar atas dasar faktor kesempatan (chance), dalam arti memiliki kesempatan yang sama, bukan karena adanya pertimbangan subjektif dari peneliti.

Responden dalam penelitian ini adalah individu-individu yang berkaitan dengan kegiatan manajemen persediaan barang dagangan. Jumlah responden untuk variabel Pengaruh Manajemen Persediaan Barang Dagang terdiri dari manager, chief operation, accounting, staff finance, adm. Finance, supervisor. Jumlah responden untuk variabel dependen Perputaran Persediaan Barang Dagang terdiri dari buyer, receiving goods, staf gudang, adm. Gudang. Responden tersebut dipilih berdasarkan pertimbangan akan adanya keterlibatan waktu, tenaga, dan fasilitas karena peneliti mengganggap bahwa pejabat tersebut bertanggung jawab dalam menguasai masalahmasalah yang berkaitan dengan penelitian yang sedang dilakukan. Rumus yang digunakan dalam penentuan sampel adalah sebagai berikut :

$$
n=N / 1+N e^{2}
$$

Keterangan:

$$
\begin{array}{ll}
\mathrm{n} & =\text { Jumlah Sampel } \\
\mathrm{N} & =\text { Jumlah Populasi } \\
\mathrm{e} & =\text { Kelonggaran ketidaktelitian karena } \\
& \text { kesalahan pengambilan sampel yang } \\
& \text { dapat di tolerir, } 15 \%
\end{array}
$$

\section{Operasionalisasi Variabel}

Untuk menyelidiki apakah manajemen persediaan barang dagang mempengaruhi perputaran persediaan barang, maka penulis memisahkan objek penelitian kedalam dua variable, yaitu Variabel Bebas (Variabel Independent) dan Variabel Tidak Bebas (Variabel Dependent).Nama Variabel, Indikator, Skala dan Instrumen Pengukuran dapat dilihat pada Tabel 1.

\section{Analisis Data}

Analisis data pada penelitian ini bersifat kualitatif. Dalam metode analisis atau perhitungan, peneliti menggunakan metode analisis uji validitas, uji reliabilitas, Method of Succesive Interval (MSI), Model Garis Kontinum, dan Uji Korelasi Spearman Rank.

Pengujian validitas dilakukan dengan menghitung korelasi antara masing-masing pertanyaan dengan skor total. Analisis ini digunakan untuk mengetahui pernyataan mana yang valid dengan mengacu pada tingkat signifikan sebesar 0,3 ( $r_{s}$ kritis). Jika $r$ korelasi $<0,3$ maka pernyataan tidak valid, sedangkan jika $r_{s}$ korelasi $>0,3$ maka pernyataan valid (Sugiyono, 2011). Dalam penelitian ini metode yang digunakan dalam uji validitas adalah korelasi Rank Spearman, yang dihitung dengan persamaan berikut:

5| Jurnal Aset (Akuntansi Riset) Vol.7| No.1 | 2015 


$$
\mathrm{r}_{\mathrm{xy}}=\frac{\sum x y}{\sqrt{\left(\sum x^{2}\right)\left(\sum y^{2}\right)}}
$$

Instrumen dikatakan valid, jika koefisien korelasi hasil perhitungan mempunyai nilai lebih besar atau $=0,3$ (angka kritis).

Tabel 1. Nama Variabel, Indikator, Skala dan Instrumen Pengukuran

\begin{tabular}{|c|c|c|c|c|c|}
\hline Variabel & Konsep Variabel & Indikator & Skala & Instrumen & $\begin{array}{c}\text { No } \\
\text { Kuesioner }\end{array}$ \\
\hline $\begin{array}{c}\text { Variabel Independen }(X) \\
\text { Pengawasan Persediaan } \\
\text { Barang Dagang }\end{array}$ & \begin{tabular}{|} 
Pengawasan persediaan adalah \\
rangkaian keputusan dan \\
kebijakan perusahaan untuk \\
memastikan perusahaan mampu \\
menyediakan persediaan dengan \\
mutu, waktu, dan jumlah tertentu \\
(Harsanto, 2007)
\end{tabular} & $\begin{array}{l}\text { - Pengawasan mutu : } \\
\text { - Pemesanan barang dagang } \\
\text { - Kualitas Model/ Out of Date } \\
\text { - Pengawasan waktu : } \\
\text { - Peramalan permintaan } \\
\text { - Alternatif Biaya Rendah } \\
\text { - Pengawasan jumlah : } \\
\text { - Perhitungan sisa barang }\end{array}$ & Ordinal & Kuesioner & $4-6$ \\
\hline $\begin{array}{c}\text { Variabel Dependen }(\mathrm{Y}) \\
\text { Pengelolaan Perputaran } \\
\text { Persediaan Barang }\end{array}$ & $\begin{array}{c}\text { Pengelolaan perputaran } \\
\text { persediaan barang dagangan } \\
\text { merupakan aktivitas yang selalu } \\
\text { melekat pada persediaan barang } \\
\text { dagangan karena melalui } \\
\text { pengelolaan perputaran } \\
\text { persediaan barang dagangan } \\
\text { yang efektif akan memberikan } \\
\text { pendapatan yang maksimal bagi } \\
\text { perusahaan (Willon and } \\
\text { Campbell, 2000). }\end{array}$ & - Efektifitas & Ordinal & Kuesioner & $1-8$ \\
\hline
\end{tabular}

Metode yang digunakan untuk uji reliabilitas adalah split half method (Spearman Brown Correlation) atau teknik belah dua yaitu dengan persamaan sebagai berikut:

$$
r_{i}=\frac{2 r_{b}}{1+r_{b}}
$$

Hasil dikatakan reliable apabila nilai koefisien reliabilitas bersifat positif. Interpretasi nilai keeratan hubungan dapat dilihat pada Tabel 2, dimana makin besar nilai koefisien reabilitas menunjukan makin handal instrumen variabel tersebut.

Tabel 2. Interpretasi Nilai Keeratan Hubungan

\begin{tabular}{|c|c|}
\hline Indeks Hubungan & Kriteria \\
\hline $0-<0,2$ & Sangat Rendah \\
$\geq 0,2-<0,4$ & Rendah \\
$\geq 0,5-<0,7$ & Sedang \\
$\geq 0,8-<0,9$ & Tinggi \\
$\geq 0,9-<1.0$ & Sangat Tinggi \\
\hline
\end{tabular}

Sumber : Sugiono, 2010.

Sebelum data dianalisis lebih lanjut, untuk data berskala ordinal perlu dirubah menjadii interval dengan teknik Method of Sucessive Interval. Selanjutnya Model Garis Kontinum digunakan untuk menganalisa, mengukur, dan menunjukkan seberapa besar tingkat kekuatan variabel yang sedang diteliti, sesuai dengan instrumen yang digunakan.Model garis kontinum ini menggunakan perhitungan skor yang dijelaskan pada rumus berikut : 
Penentuan skor $=\frac{\text { Nilai presentase } \text { max }- \text { Nilai } p r}{\text { Skala nilai } \text { (instrumt }}$

Sedangkan untuk menguji hubungan dua yang diteliti dalam penelitian ini, peneliti menggunakan teknis korelasi tata jenjang atau rank correlation atau sering juga disebut uji korelasi Spearman Rank. Alasan peneliti menggunakan teknik ini karena data dari instrumen penelitian menggunakan skala likert hasilnya berupa data ordinal atau berjenjang. Adapun rumus Spearman Rank yaitu :

$$
\rho=1-\frac{6 \sum b_{t}^{2}}{n\left(n^{2}-1\right)}
$$

dimana,

$\rho \quad=$ Koefisien korelasi Spearman Rank

$n \quad=$ Banyaknya ukuran sampel

$\sum b_{t}^{2}=$ Jumlah kuadrat dari selisih rank

Variabel X dengan Rank Variabel Y
Uji Validitas Instrumen

Berdasarkan hasil pengolahan data menggunakan SPSS Versi 24 diperoleh hasil uji validitas sebagai berikut:

\section{Uji Validitas Pengawasan Persediaan Barang Dagang}

Tabel 3 dibawah ini menyajikan hasil uji validitas terhadap pernyataan Pengawasan Persediaan Barang Dagang.Pada Tabel 3, dapat dilihat nilai koefisien dari setiap butir pernyataan lebih besar dari nilai $t_{\text {hitung }} 0.396$. Hasil pengujian ini menunjukkan bahwa semua butir pernyataan untuk Pengawasan Persediaan Barang Dagang sudah valid dan layak digunakan sebagai alat ukur penelitian serta dapat digunakan untuk analisis selanjutnya.

\section{HASIL DAN PEMBAHASAN}

Tabel 3. Hasil Uji Validitas Pengawasan Persediaan Barang Dagang

\begin{tabular}{|c|c|c|c|}
\hline Butir Pernyataan & R Hasil & RHitung=0,355 & Hasil \\
\hline Item 1 & 0,634 & 0,396 & Valid \\
Item 2 & 0,450 & 0,396 & Valid \\
Item 3 & 0,622 & 0,396 & Valid \\
Item 4 & 0,976 & 0,396 & Valid \\
Item 5 & 0,527 & 0,396 & Valid \\
Item 6 & 0,430 & 0,396 & Valid \\
Item 7 & 0,586 & 0,396 & Valid \\
Item 8 & 0,452 & 0,396 & Valid \\
Item 9 & 0,527 & 0,396 & Valid \\
Item 10 & 0,515 & 0,396 & Valid \\
Item 11 & 0,472 & 0,396 & Valid \\
\hline
\end{tabular}

Sumber: Lampiran Output Uji Validitas dan Reliabilitas

\section{Uji Validitas Pengolahan Perputaran Persediaan Barang}

Tabel 4, menyajikan hasil uji validitas terhadap pernyataan Pengolahan Perputaran Persediaan Barang.Pada tabel 4, dapat dilihat nilai koefisien korelasi ( $r)$ dari setiap butir pernyataan lebih besar dari nilai kritis 0.396 . Hasil pengujian ini menunjukkan bahwa semua butir pernyataan untuk variabel $Y$ sudah valid dan layak digunakan sebagai alat ukur penelitian serta dapat digunakan untuk analisis selanjutnya. 
Tabel 4. Hasil Uji Validitas Pengolahan Perputaran Persediaan Barang

\begin{tabular}{|c|c|c|c|}
\hline Butir Pernyataan & R Hasil & RHitung=0,396 & Hasil \\
\hline Item 12 & 0,496 & 0,396 & Valid \\
Item 13 & 0,453 & 0,396 & Valid \\
Item 14 & 0,451 & 0,396 & Valid \\
Item 15 & 0,415 & 0,396 & Valid \\
Item 16 & 0,457 & 0,396 & Valid \\
Item 17 & 0,574 & 0,396 & Valid \\
Item 18 & 0,407 & 0,396 & Valid \\
\hline
\end{tabular}

Sumber: Lampiran Output Uji Validitas dan Reliabilitas

\section{Uji Reliabilitas Instrumen}

Hasil pengolahan menggunakan metode cronbach alphauntuk uji reliabilitas kuesioner masing-masing variable dapat dilihat pada Tabel 5. Semua variabel memiliki nilai cronbach alpha yang lebih besar dari nilai kritis yang direkomendasikan yakni sebesar 0,6 dan dinyatakan reliabel, sehingga dapat disimpulkan bahwa seluruh pernyataan yang digunakan sudah teruji kesahihan (validity) serta konsistensinya (reliability) untuk dapat digunakan sebagai alat ukur penelitian.

Tabel 5. Hasil Uji Reabilitas

\begin{tabular}{|c|c|c|c|}
\hline Variabel & $\begin{array}{c}\text { Cronbach } \\
\text { Alpha }\end{array}$ & $\begin{array}{c}\text { Nilai } \\
\text { Kritis }\end{array}$ & Hasil \\
\hline X & 0,778 & 0,6 & Reliable \\
Y & 0,631 & 0,6 & Reliable \\
\hline
\end{tabular}

Sumber: Lampiran Output Uji Validitas dan Reliabilitas

\section{Analisis Pengawasan Persediaan Barang Dagang pada Toserba Yogya}

Berdasarkan pengolahan data hasil penyebaran kuesioner yang terdiri dari butir pernyataan untuk Indepedensi, kemudian dilakukan perhitungan total skor dengan tabulasi jawaban responden mengenai Manajemen Persediaan Barang Dagang, didapatkan rata-rata skor sebesar 49,08. Nilai ini termasuk kedalam kriteria "Sangat Berkualitas" berdasarkan Pedoman Kategorisasi Indepedensi dalam Sugiono (2010).

\section{Analisis Pengolahan Perputaran Persediaan Barang Pada Toserba Yogya}

Berdasarkan pengolahan data hasil penyebaran kuesioner yang terdiri dari butir pernyataan untuk Pengelolaan Perputaran Persediaan Barang, rata-rata skor jawaban responden sebesar 33,6, dimana nilai tersebut dapat dikategorikan sebagai kategori "Baik".

\section{Analisis Garis Kontinum Deskriptif Variabel Pengawasan Persediaan Barang Dagang}

Variabel X diukur dengan 3 dimensi yaitu, Mutu, Waktu dan Jumlah. Gambaran penilaian responden penelitian untuk setiap dimensi dapat dilihat pada Garis Kontinum variabel X yang disajikan pada Gambar 1. Total skor untuk penilaian responden mengenai dimensi Mutu Di Toserba Yogya diperoleh sebesar 365. Dengan skor sebesar 365 atau 147,3\% dari skor ideal maka Mutu X pada Toserba Yogya dinilai oleh responden penelitian sudah "sangat baik". Total skor untuk penilaian responden mengenai dimensi waktu diperoleh sebesar 342. Dengan skor sebesar 342 atau 144\% dari skor ideal, termasuk dalam kategori "sangat baik". Sedangkan total skor untuk penilaian responden mengenai dimensi jumlah diperoleh sebesar 341.Dengan skor sebesar 341 atau $68,2 \%$ dari skor ideal maka waktu X pada 
Toserba Yogya dinilai oleh responden penelitian masih "kurang baik".

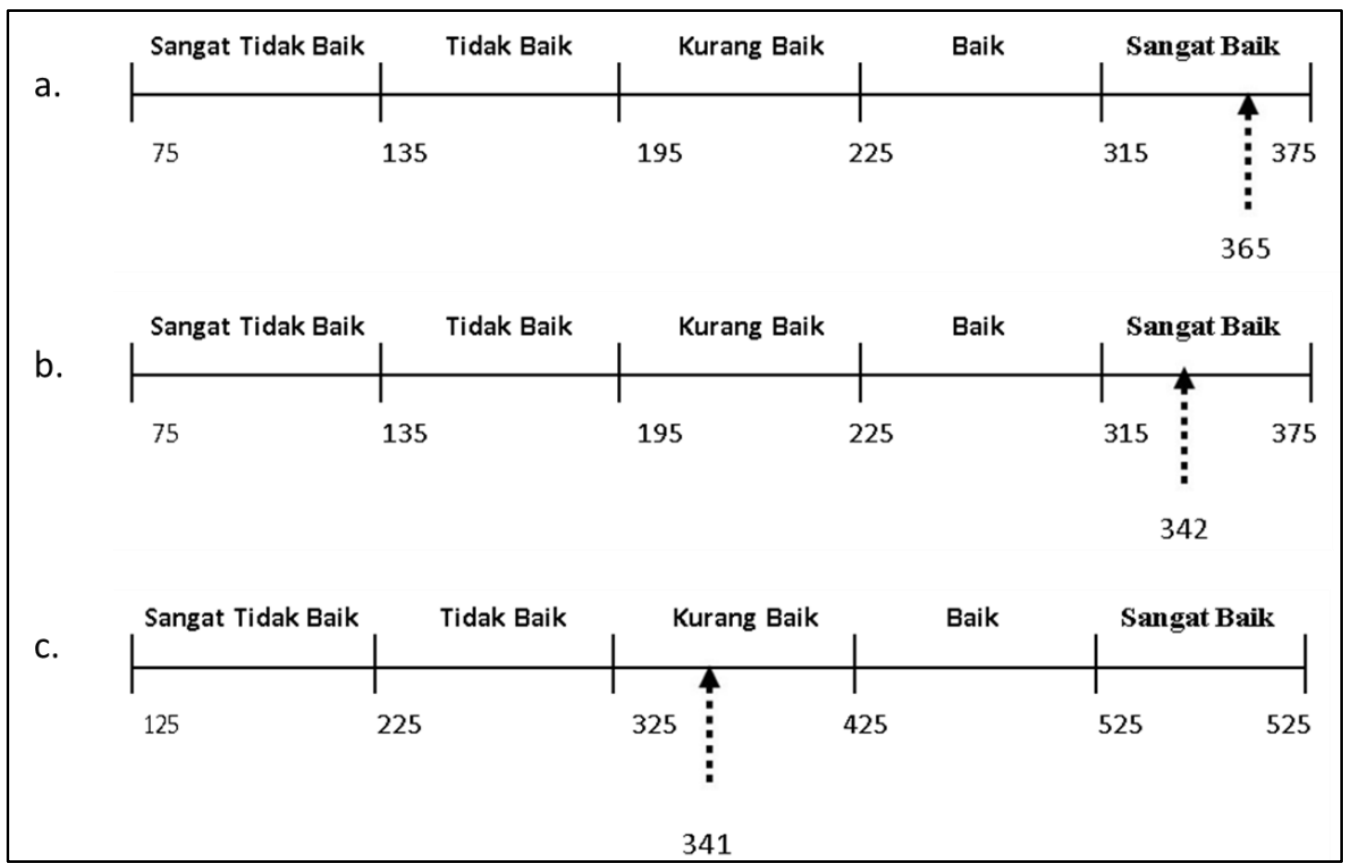

Gambar 1. Rentang Skor Garis Kontinum Variabel X untuk dimensi (a) Mutu, (b) Waktu dan (c) Jumlah

\section{Deskriptif Variabel Pengelolaan \\ Perputaran Persediaan}

Variabel Y diukur dengan 2 dimensi, yaitu harga pokok penjualan dan rata-rata persediaan.Gambaran penilaian responden penelitian untuk setiap dimensi dapat dilihat pada garis kontinum variabel $\mathrm{Y}$ yang ditunjukan pada Gambar 2.Hasil penilaian responden mengenai hasil tanggapan responden mengenai dimensi Jumlah Y pada Toserba Yogya menunjukan skor sebesar 308 atau 61,6\% dari skor ideal maka HPP Y pada
Toserba Yogya dinilai oleh responden penelitian kedalam kategori "Tidak Baik". Sedangkan hasil penilaian responden mengenai hasil tanggapan responden mengenai

dimensi Rata-rata Persediaan pada Toserba Yogya masuk dalam kategori "baik", dengan skor sebesar 307 atau 102,3\% dari skor ideal. 


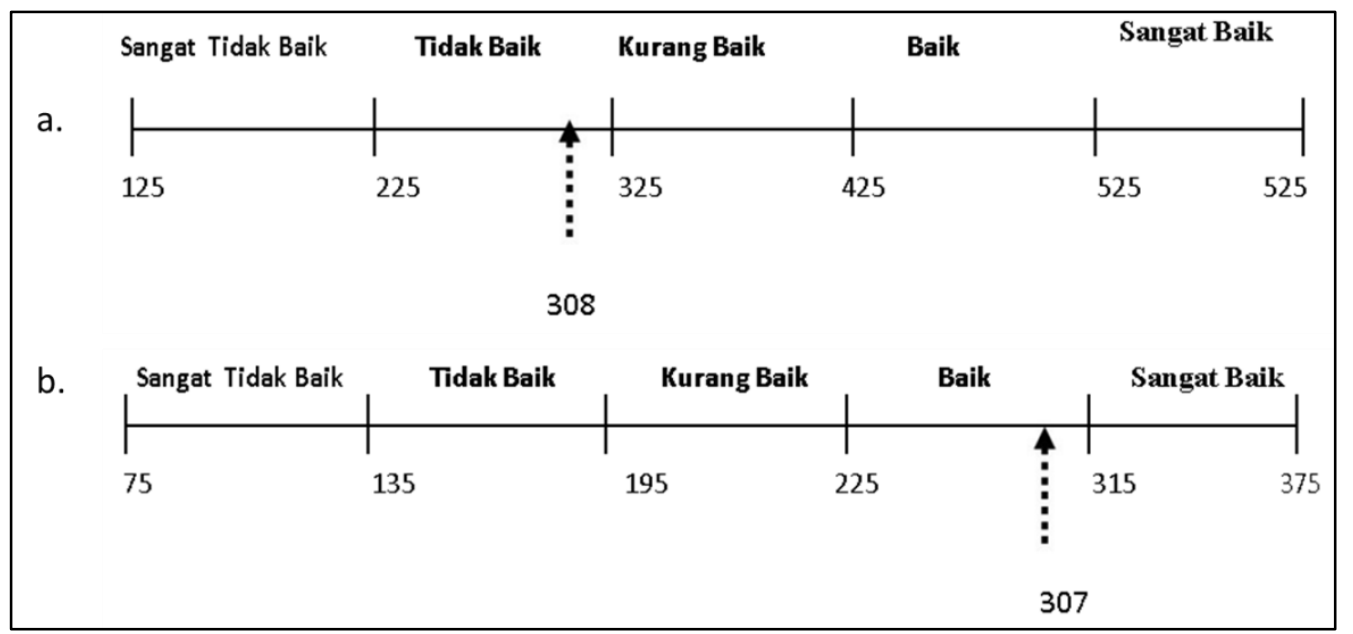

Gambar 2. Rentang Skor Garis Kontinum Variabel Y untuk dimensi (a) Harga Pokok Penjualan dan (b) Rata-rata Persediaan

\section{Analisis Korelasi Rank Spearman}

Untuk mengetahui bagaimana tingkat keratan hubungan antara variabel bebas dengan variabel terikat dilakukan perhitungan korelasi antara variabel bebas dengan variabel terikat menggunakan IBM SPSS Statistics Versi 24.Berdasarkan tabel output (lihat Tabel 6) terlihat bahwa nilai koefisien korelasi yang diperoleh antara $\mathrm{X}$ dengan $\mathrm{Y}$ adalah sebesar
0.968 atau 96,8\%. Nilai korelasi bertanda positif yang menunjukkan bahwa hubungan yang terjadi antara variabel bebas dengan variabel terikat adalah searah, dimana semakin baik Pengawasan Persediaan Barang Dagang maka akan diikuti semakin meningkatnya Pengelolaan Perputaran Persediaan Barang.

Tabel 6. Analisis Korelasi Pengawasan Persediaan Barang Dagang dengan Pengelolaan Perputaran Persediaan Barang

\begin{tabular}{|c|c|c|c|c|}
\hline & & & $\mathrm{x}$ & Y \\
\hline \multirow[t]{6}{*}{ Spearman's rho } & \multirow[t]{3}{*}{$\mathrm{x} 1$} & Correlation Coefficient & 1.000 & $.968^{* *}$ \\
\hline & & Sig. (2-tailed) & & .000 \\
\hline & & $\mathrm{N}$ & 25 & 25 \\
\hline & \multirow[t]{3}{*}{$y$} & Correlation Coefficient & $.968^{* t}$ & 1.000 \\
\hline & & Sig. (2-tailed) & .000 & \\
\hline & & $\mathrm{N}$ & 25 & 25 \\
\hline
\end{tabular}

*t. Correlation is significant at the 0.01 level (2-tailed).

Gambar 1. Perubahan Kinerja Keuangan

\section{SIMPULAN}

Pengawasan Persediaan Barang Dagang pada Toserba Yogya sudah dapat dikatakan "Sangat Berkualitas" hingga saat ini seperti halnya dari pemesanan barang dagang yang masih dalam jumlah yang wajar, hal ini dapat diperkuat juga dari indikator Mutu, Waktu dan Jumlah masuk dalam kriteria "Sangat Berkualitas".
Pengelolaan Perputaran Persediaan Barang pada Toserba Yogya juga sudah dapat dikatakan "Baik" dilihat dari cepatnya pengelolaan perputaran barang yang ada selalu mengalami peningkatan walaupun tidak tinggi. Hal ini juga dapat dilihat dari hasil kuesioner indikator Harga Pokok Penjualan dan Rata-rata Persediaan termasuk dalam kriteria "Baik". 
Pengawasan Persediaan Barang Dagang berpengaruh signifikan terhadap Pelaksanaan Self Assessment System dengan kontribusi pengaruh sebesar 95,8\%. Dalam hal ini jika semakin baik Pengawasan Persediaan Barang Dagang yang diterapkan perusahaan maka Pengelolaan Perputaran Persediaan Barang semakin baik.

Pada penelitian berikutnya objek penelitian dapat diperluas dengan mengikutsertakan variabel lainnya yang dapat mempengaruhi baiknya pengelolaan perputaran persediaan, serta menambah teori-teori baru untuk memperkaya penelitian.

\section{DAFTAR PUSTAKA}

Arens, A. Loebbecke, J.K., 2003. Auditing Pendekatan Terpadu buku satu. Edisi Indonesia. Terjemahan Jusuf, Amir A. Jakarta: Salemba Empat.

Harahap, Sofyan Syafri., 2006. Analisis Kritis Atas Laporan Keuangan. Jakarta: PT. Raja Grafindo Persada.

Ikatan Akuntan Indonesia., 2008. Standar Akuntansi Keuangan; PSAK No.14. Jakarta: Salemba Empat.

Indrajit, RE dan Djoko Pranoto, R., 2003. Manajemen Persediaan. Jakarta: Grasindo

La Midjan dan Susanto, Azhar., 2001. Sistem Informasi Akuntansi 1 Edisi 8,Bandung : Lingga Jaya

Simbolon,M. Masry., 2004. Dasar-dasar Administrasi Dan Manajemen. Jakarta: Penerbit Ghalia Indonesia.

Sugiyono., 2010. Statistika Untuk Penelitian. Bandung: CV. Alfabeta.

Supriyono, A. R., 2000. Perencanaan dan Pengendalian Biaya serta Pembuatan Keputusan, Edisi Kedua, Cetakan Keempat. Yogyakarta: Bagian Penerbitan Fakultas Ekonomi Universitas Gadjah Mada, hal 257.

Syamsudin,Lukman., 2002.Manajemen Keuangan Perusahaan, Edisi Baru, Cetakan Ketujuh. Jakarta: PT. Raja Grafindo Persada.
Wilson, J.D., and Campbell, J.B., 2001. Controllership, third edition, yang diterjemahkan oleh Tjintjin Fenix Tjendera, Jakarta: Erlangga. 